\title{
Phytoecia (musaria) argus (Frölich, 1793), a new longhorn beetle (Coleoptera: Cerambycidae) for the fauna of Serbia
}

\author{
Dejan V. Stojanović \\ University of Novi Sad, Institute of Lowland Forestry and Environment, Novi Sad, Serbia \\ Corresponding author: Dejan V. Stojanović; E-mail: dejanstojanovic021@yahoo.co.uk
}

Received: 4 Jun 2021; Revised: 11 Jun 2021; Accepted: 14 Jun 2021

\begin{abstract}
In total, 550 species of longhorn beetles (Cerambycidae) exist in Europe. The most recent checklist of Cerambycidae family of Serbia cited 265 species and 92 subspecies, belonging to 109 genera, 48 tribes, and six subfamilies in the country. However, the presence of 28 species reported from Serbia is questionable. Here we present the first finding of Phytoecia (Musaria) argus (Frölich, 1793) for the fauna of Serbia. The species was collected in May and June 2018 on Stol mountain (near the town of Bor, eastern Serbia). Additionally, data on morphology, bionomy and distribution of the longhorn beetle species are given. With this finding, the total number of longhorn beetle species in Serbia is estimated at 266. This species could be used as an indicator for the assessment of the nature value and conservation status of natural habitats in Serbia and Europe.
\end{abstract}

Keywords: Cerambycidae, Phytoecia (Musaria) argus, Stol mountain, fauna, distribution, morphology.

\section{Introduction}

According to the data of several authors (Adamović 1950, 1965; Gnjatović and Žikić, 2011; Ilić, 2005; Mikšić and Georgijević 1971, 1973; Mikšić and Korpič, 1985; Pil and Stojanović, 2005, 2009; Pil and Stanković, 2006), there are 260 species of longhorn beetles (Coleoptera: Cerambycidae) in Serbia. However, Pavićević et al. (2015) reported the presence of 550 species of longhorn beetles for Europe and 228 species of Cerambycidae for Serbia, and suggested that new species for the fauna of the country could be expected in future. Finally, Ilić and Ćurčić (2015) presented the most recent checklist of the family Cerambycidae of Serbia based on the data gathered by the authors and from all previous literature. These authors cited 265 longhorn beetle species and 92 subspecies belonging to 109 genera, 48 tribes and six subfamilies for Serbia. However, they pointed out that the presence of 28 species recorded in Serbia is questionable.

During 2018, the author collected one interesting longhorn beetle species on Stol mountain (Mt. Stol) (near the town of Bor, eastern Serbia). Its detailed analysis revealed that it is new for the fauna of Serbia. In this paper, the results of the research are presented.

Gradinarov and Gjonov (2020) have recently found the same species in Western Bulgaria and highlighted that the species may be useful as an indicator species for the assessment of the conservation status of natural steppe habitats in Europe. 


\section{Material and methods}

The author conducted field trips on Mt. Stol in May and June 2018. The specimens of Phytoecia (Musaria) argus (Frölich, 1793) were collected manually using entomological net. The collected adults of Cerambycidae were prepared and stored as dry specimens in entomological boxes in the private collection of the author.

Identification was made using the keys of Bense (1995) and Sama (2002). Data on bionomy and distribution were taken from Althoff and Danilevsky (1997), Bense (1995), Danilevsky (2020, 2021) and Sama (2002). A map with UTM grids $(10 \times 10 \mathrm{~km})$ showing the only locality of the longhorn beetle species in Serbia is given in Figure 1. The photo of the locality where the longhorn beetle species was found is given in Figure 2a.

Mt. Stol (1155 m a.s.l.) is situated in the Carpathian part of eastern Serbia, near the town Bor (Figure $2 b$ ). The diverse ecological conditions, uninhibitedness and a relative isolation of this area result in the great wealth of biodiversity on a relatively small area (Ranđelović et al. 2006). The same authors highlighted the significance of further floristic and faunistic studies of Mt. Stol, due to its specificity, as well as still neglected anthropogenic impact, despite the relative vicinity of the industry of the copper mine Bor.

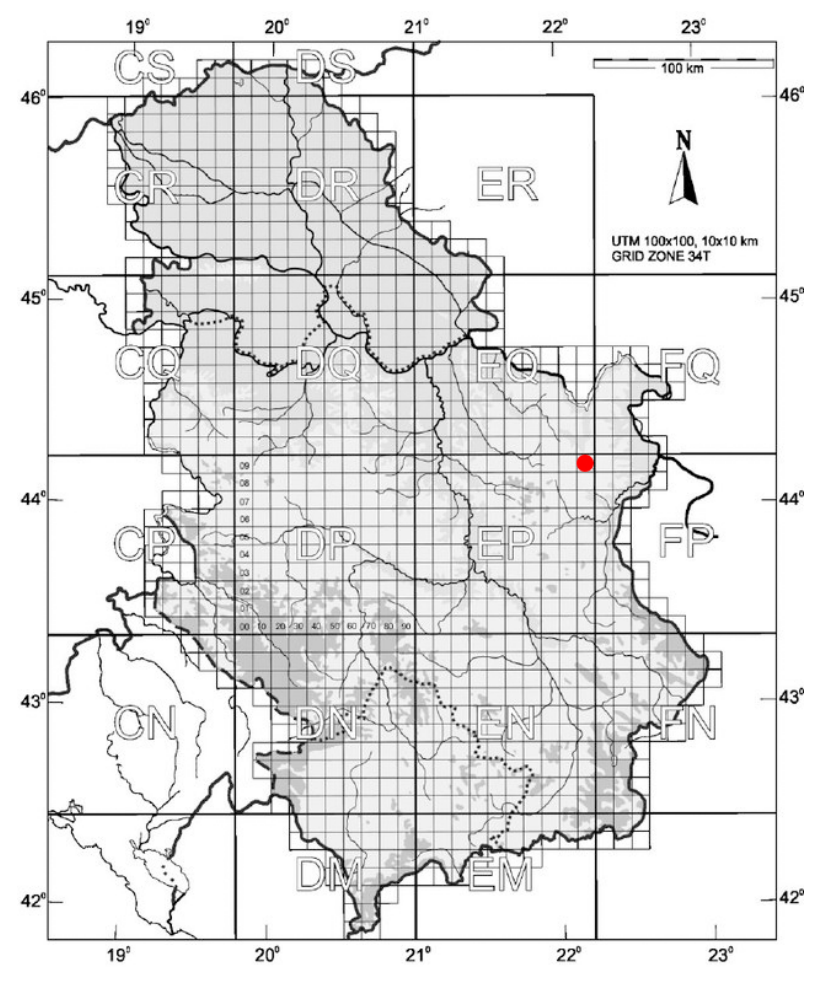

Figure 1. A UTM map of Serbia with the locality (red dot) of finding of Phytoecia (Musaria) argus in the country.

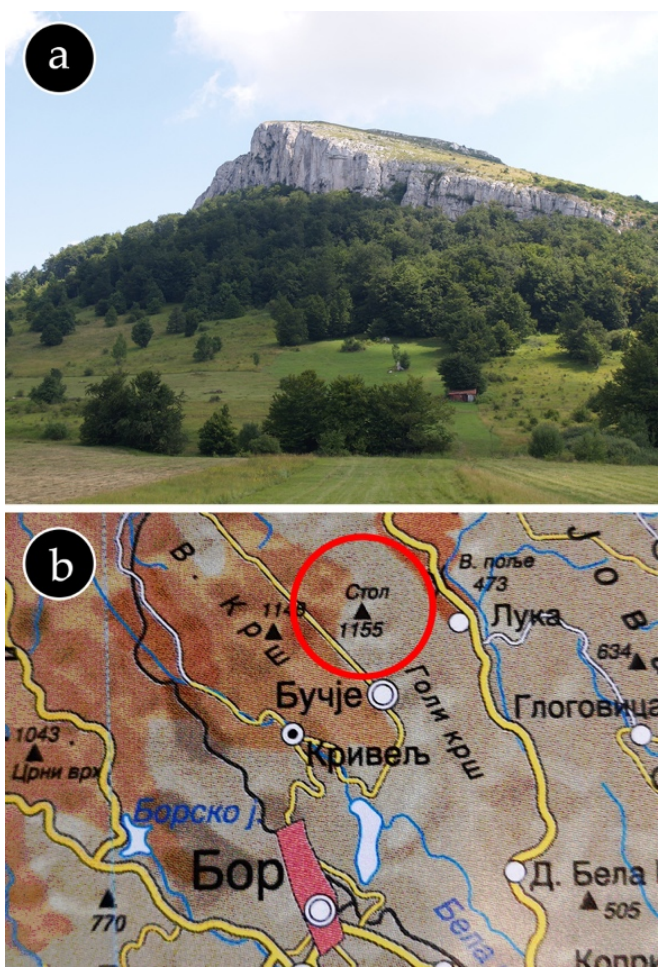

Figure 2. a) Stol Mountain (1155 m a.s.l.), b) locality of field research (photo: Stojanović, D.V.).

The photograph of the locality was made using a Canon EOS 5D digital camera, equipped with a CANON lens EF $50 \mathrm{~mm}, 1: 1.8$. Insect specimens and genital armature were photographed using a Carl Zeiss Stemi 2000 stereomicroscope with a special digital photo accessory in the laboratory of the Institute of Lowland Forestry and Environment, University of Novi Sad. Images were processed using Motic ${ }^{\circledR}$ image stacking software. 


\section{Results and discussion}

\subsection{Distribution, bionomy and new finding}

The detailed reading of the previous literature on Serbian Cerambycidae (Adamović 1950, 1965; Gnjatović and Žikić, 2011; Ilić, 2005; Ilić and Ćurčić, 2015; Mikšić and Georgijević 1971, 1973; Mikšić and Korpič 1985; Pil and Stojanović, 2005, 2009; Pil and Stanković, 2006) yielded that P. (M.) argus was not recorded in Serbia until now.

Phytoecia (Musaria) argus is distributed in central, southeastern and eastern Europe (Danilevsky, 2020, 2021). It inhabits northeastern Italy, Austria, Czech Republic, Slovakia, Slovenia, Greece, Hungary, Croatia, Bosnia and Herzegovina, Bulgaria, Romania, Moldova, Ukraine and central and southern parts of European Russia (Sama, 2002; Danilevsky, 2020, 2021). Develops in herbaceous plants belonging to the family Apiaceae (Seseli varium Trevis., S. annuum L., S. tommasinii Rchb.) (Bense, 1995). Larvae feed on their roots. Adults appear from May to June on the stalks of the host-plants (Bense, 1995). Gradinarov and Gjonov (2020) cited both Trinia Hoffm. and Seseli as the host plants.

Records of Phytoecia (Musaria) argus: eastern Serbia, surroundings of the town of Bor, Mt. Stol, locality Sedlo, 900 m a.s.l., 30.05.2018, 1 ơ (leg. D.V. Stojanović) (UTM code EP99); ibid., 10.06.2018, 1 , 1 ơ (leg. D.V. Stojanović) (UTM code EP99).

\subsection{Morphological description}

Morphology (habitus in dorsal and ventral views) of one collected male and one female specimens are shown in Figures 3 and 4.

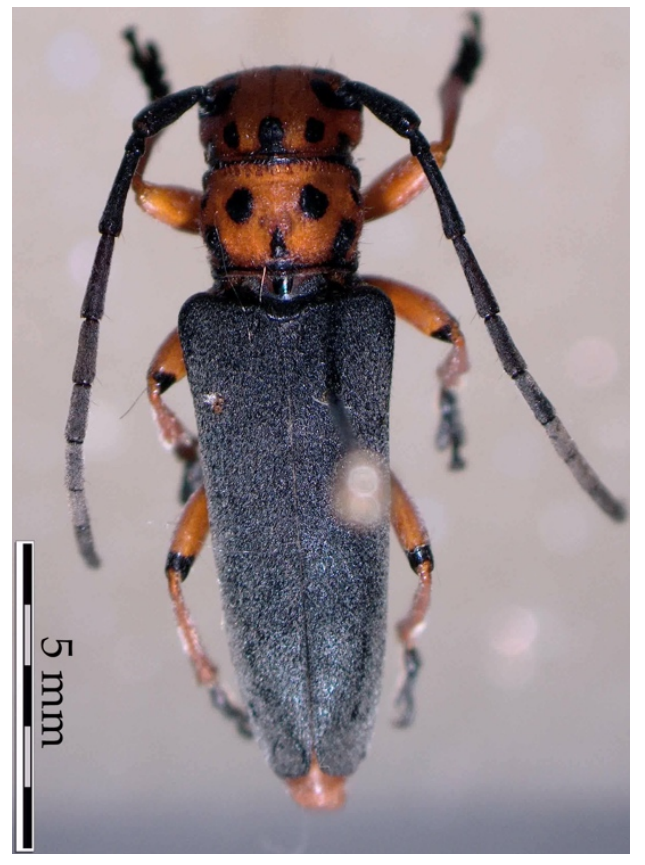

Figure 3. Phytoecia (Musaria) argus, dorsal view: morphology of a male (photo: Stojanović, D.V.).

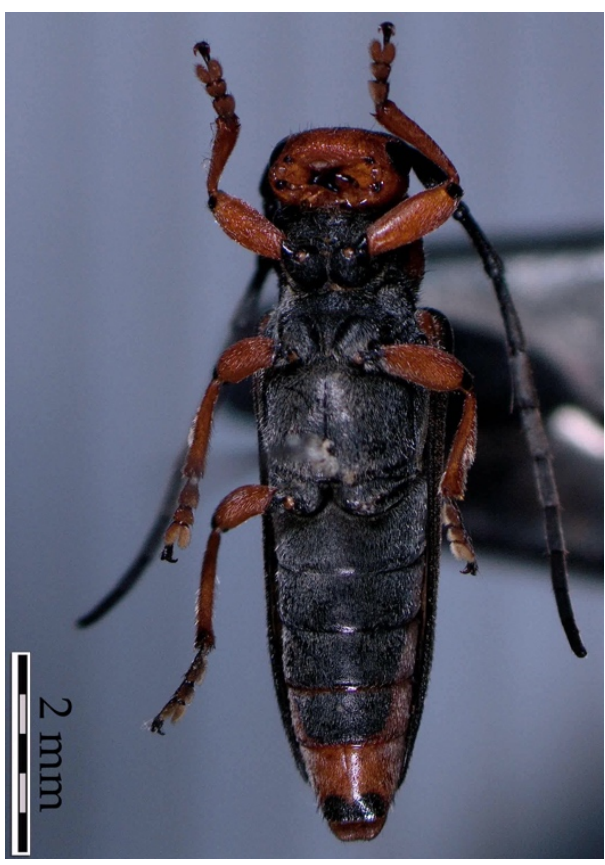

Figure 4. Phytoecia (Musaria) argus, ventral view: morphology of a female (photo: Stojanović, D.V.).

Elytral apex with a small spine at sutural angle and with another small spine at outer angle. It is very important taxonomic characteristic of the species (Figures 5 and 6). Elytra in males narrow and 2.4-2.7 times as long as wide across shoulders (Bense, 1995). Scutellum and dorsal side of elytra black, with whitish-grey pubescence. 


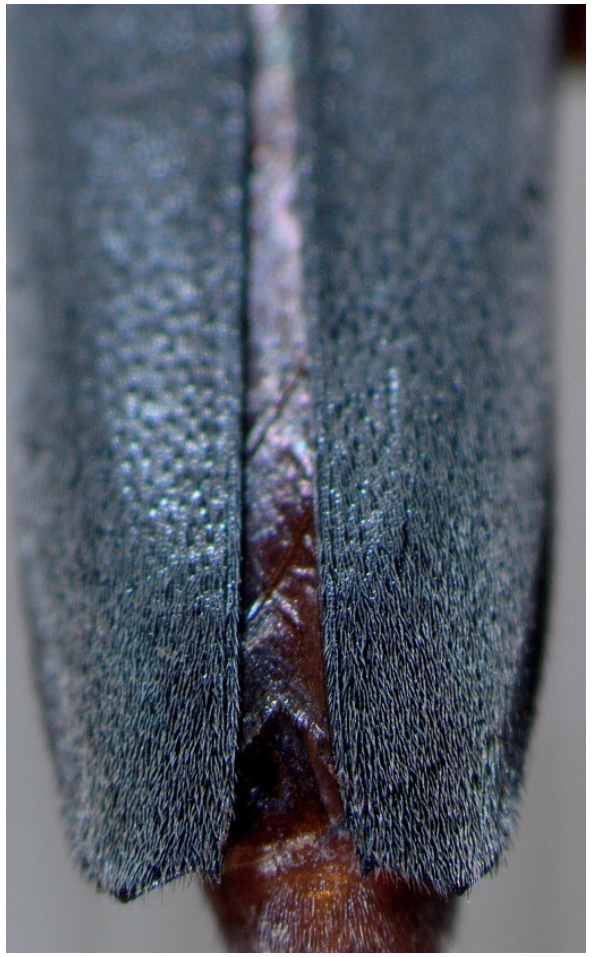

Figure 5. Phytoecia (Musaria) argus, dorsal view: Elytral apex (photo: Stojanović, D.V.).
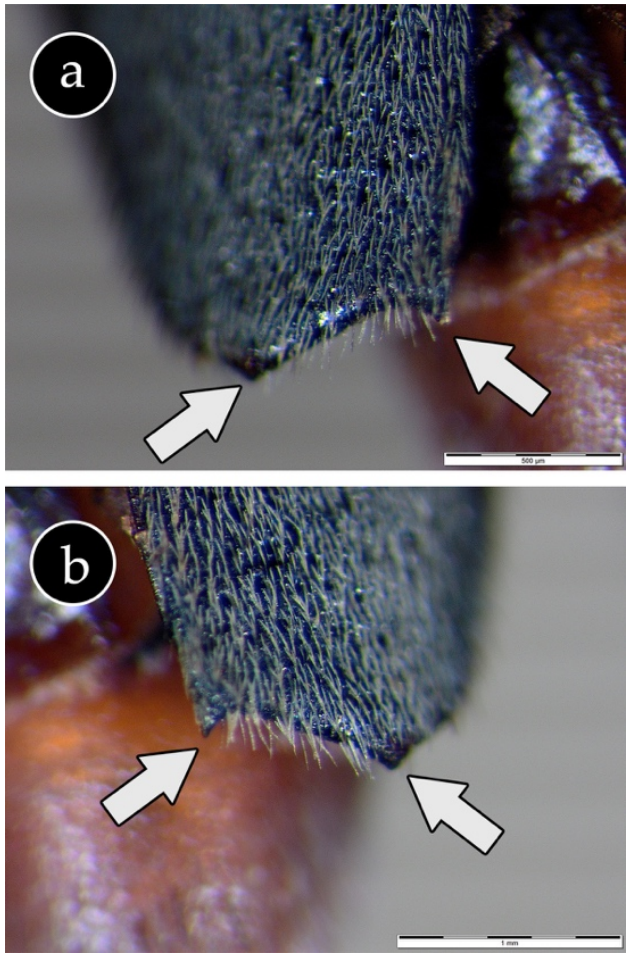

Figure 6. Phytoecia (Musaria) argus, dorsal view: enlarged elytral apex with a small spine both at the sutural angle and at the outer angle (photo: Stojanović,

$$
\text { D.V.). }
$$

Body length 9-21 mm. Head red, forehead (Figure 7) typically with three black spots between antennae, vertex with three black spots in front of pronotal anterior margin, narrow parts behind temples also black. Antennae of medium length, blackish-brown to black.

Pronotal disc typically red, with seven black spots, anterior pronotal margin and pronotal base occasionally black, black spots sometimes run together. Femora and tibiae predominantly yellowishred, with apices of femora and tibiae black (Bense, 1995). Inner margin of the apex of the penis rounded (Figure 8).

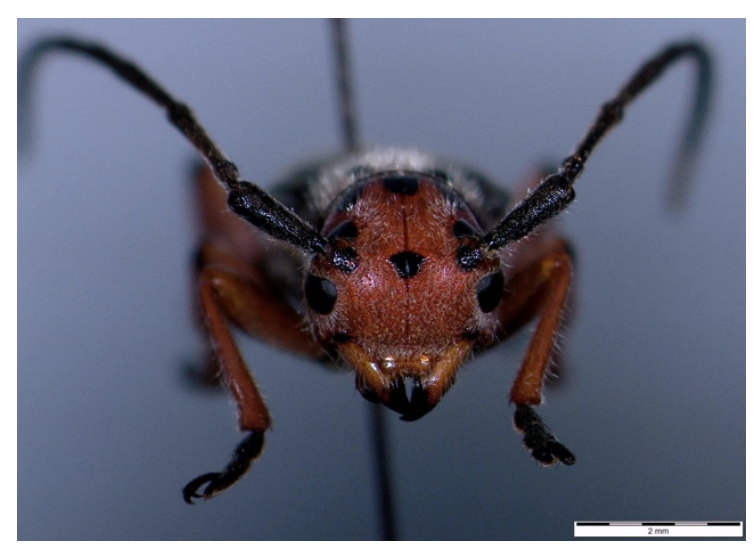

Figure 7. Phytoecia (Musaria) argus, anterior view: forehead and vertex (photo: Stojanović, D.V.).

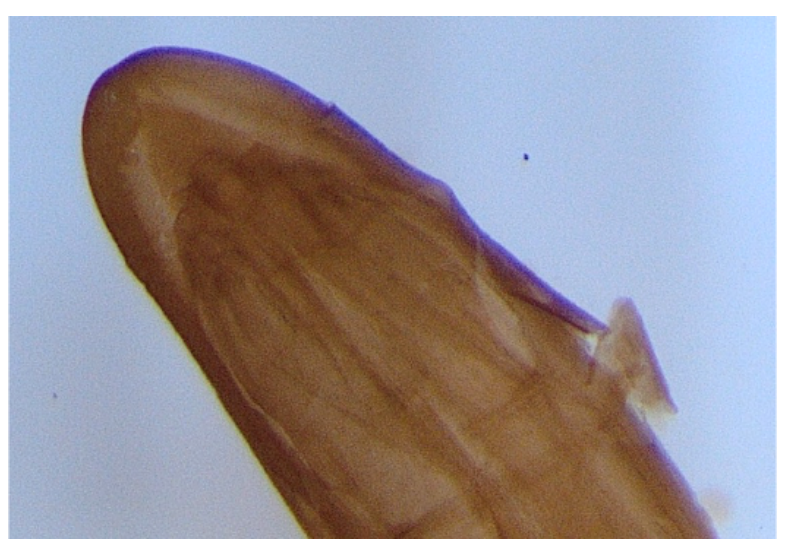

Figure 8. Phytoecia (Musaria) argus, male genitalia (inner margin of the apex of the penis rounded) (photo: Stojanović, D.V.). 


\section{Conclusions}

Here is presented the first finding of Phytoecia (Musaria) argus for the fauna of Serbia. The species was collected in May and June 2018 on Mt. Stol (near the town of Bor, eastern Serbia). The Spatial Plan of the Republic of Serbia till 2010 designated Mt. Stol as a significant area from the aspect of natural values, which supported its inclusion on the official protection programmes (Ranđelović et al. 2006). Further, a draft of the Spatial Plan of the Republic of Serbia for 2021-2035 (Anonimous, 2021) identified the Mt. Stol as the area planned for protection. Here presented finding clearly supports such assessments. Due to its natural values, and considering the real hazard related to anthropogenic factors due to vicinity of the copper mine, Mt. Stol deserves to be a protected area.

With the finding reported herein, the total number of longhorn beetle species in Serbia increased to 266 .

\section{Acknowledgement}

This study was financed by the Ministry of Education, Science and Technological Development of the Republic of Serbia (Contract No. 451-03-9/2021-14/200197).

\section{References}

1. Anonimous (2021): Prostorni plan Republike Srbije od 2021 do 2035 (nacrt), Ministry of Construction, Transport and Infrastructure, Belgrade.

2. Adamović, Ž. (1950): Zbirka Cerambycidae u Prirodnjačkom muzeju srpske zemlje. I deo: Prionini, Cerambycini. Bulletin of the Natural History Museum in Belgrade, B (3-4): 343-357.

3. Adamović, Ž. (1965): Cerambycidae (Coleoptera) collected in Serbia. Bulletin of the Natural History Museum in Belgrade, B(20): 147-183.

4. Althoff, J., Danilevsky, M.L. (1997): A Check-List of Longhorn Beetles (Coleoptera: Cerambycidae) of Europe. Slovensko entomološko društvo Štefana Michielija, Ljubljana.

5. Bense, U. (1995): Longhorn Beetles: Illustrated Key to the Cerambycidae and Vesperidae of Europe. Verlag Josef Margraf, Weidersheim.

6. Danilevsky, M.L. (Ed.) (2020): Catalogue of Palaearctic Coleoptera. Chrysomeloidea I (Vesperidae, Disteniidae, Cerambycidae). Updated and Revised Second Edition. Volume 6/1. Brill. Leiden.

7. Danilevsky, M.L. (2021): A check-list of longicorn beetles (Coleoptera: Cerambycidae) of Europe. Available from: http://www.cerambycidae.net/europe.pdf (accessed on 2 June, 2021)

8. Gnjatović, I., Žikić, V. (2011): New data on longhorn beetles for the territories of Serbia and Montenegro (Coleoptera, Cerambycidae) with the detailed description of Callimoxys gracilis (Brullé 1832). Biologica Nyssana 2(2): 119-122.

9. Gradinarov, D., Gjonov, I. (2020): New record of the steppe longhorn beetle species Phytoecia (Musaria) argus (G. F. Frölich, 1793) (Cerambycidae: Lamiinae) in Bulgaria. ZooNotes. 155: 1-4.

10. Ilić, N. (2005): Strižibube Srbije (Coleoptera: Cerambycidae): faunistički pregled. SZGR "Joksimović", Beograd.

11. Ilić, N., Ćurčić, S. (2015): A checklist of longhorn beetles (Coleoptera: Cerambycidae) of Serbia. Zootaxa 4026(1): 1-97.

12. Mikšić, R., Georgijević, E. (1971): Cerambycidae Jugoslavije, I deo. Academy of Sciences and Arts of Bosnia and Herzegovina, Sarajevo.

13. Mikšić, R., Georgijević, E. (1973): Cerambycidae Jugoslavije, II deo. Academy of Sciences and Arts of Bosnia and Herzegovina, Sarajevo.

14. Mikšić, R., Korpič, M. (1985): Cerambycidae Jugoslavije, III deo. Academy of Sciences and Arts of Bosnia and Herzegovina, Sarajevo. 
15. Pavićević, D., Ilić, N., Đurić, M. (2015): Strižibube Srbije: priručnik. Institute for Nature Conservation of Serbia \& Habiprot, Belgrade.

16. Pil, N., Stojanović, D.V. (2005): New longhorn beetles (Coleoptera: Cerambycidae) from Serbia and Montenegro. Archives of Biological Sciences 57(2): 143-146.

17. Pil, N., Stojanović, D.V. (2009): Theophilea subcylindricollis Hladil, 1988, a new longhorn beetle (Coleoptera: Cerambycidae) for Serbian fauna. Acta entomologica serbica. 14(1): 125-128.

18. Ranđelović, D., Stojanović, D.V., Jakšić, P. (2006): Biodiversity of Mt. Stol - the base of the assessment of its biocoenosis conservation. International Scientific Conference in Occasion of 60 Years of Operation of the Institute of Forestry in Belgrade, 8-10th November 2006, Donji Milanovac, Serbia: 505-512.

19. Sama, G. (2002): Atlas of the Cerambycidae of Europe and the Mediterranean Area. Vol. 1. Northern, Western, Central and Eastern Europe. British Isles and Continental Europe from France (excl. Corsica) to Scandinavia and Urals. Kabourek, Zlín. 